\title{
YEZIDI TEXTS (Continued) ${ }^{1}$
}

\author{
By Isya Joseph \\ New York City, N. Y. \\ TRANSLATION
}

\section{In the Name of the Most Compassionate God!}

With the help of the Most High God, and under his direction, we write the history of the Yezidis, their doctrines, and the mysteries of their religion, as contained in their books, which reached our hand with their own knowledge and consent.

In the time of Al-Muktadir Billah, А. H. $295,{ }^{48}$ there lived Manșûr-al-Hallâj, ${ }^{40}$ the wool-carder, and Seibg 'Abd-al-Kâdir of Jîlân. ${ }^{50}$ At that time, too, there appeared a man by the name of Seib 'Adî, from the mountain of Hakkari, ${ }^{51}$ originally from the region of Aleppo or Baalbek. He came and dwelt in Mount Lališs, ${ }^{52}$ near the city of Moṣul, about nine hours distant from it. Some say he was of the people of Harrân, and related to Marwân ibn-al-Ḥakam. His full name is Šaraf ad-Dîn Abû-l-Faḍ̂̂িl, 'Adî bn Musâfir bn Ismael bn Mousa bn Marwân bn Al-Ḥasan bn Marwân. He died A. H. 558 (A. D. 1162-63). His tomb is still visited; it is near $\mathrm{Ba}$ adrei, one of the villages of Mosul, distant eleven hours. The Yezidis are the progeny of those who were the murids (disciples) of Seih 'Adî. Some trace their origin to Yezid, ${ }^{53}$ others to Ḥasan-Al-Bașrî. ${ }^{54}$

\section{AL-JILWAH (THE REVELATION)}

Before all creation this revelation was with Melek Tâ'us, who sent 'Abd Tâ'us to this world that he might separate truth from error and make truth known to his particular people. This was done, first of all, by means of oral tradition, and afterward by means of this book, Al-Jilwah, which the outsiders may neither read nor behold.

1 See the January issue of this Journal for the Arabic text. 


\section{CHAPTER I}

I was, am now, and shall have no end. I exercise dominion over all creatures and over the affairs of all who are under the protection of my image. I am ever present to help all who trust in me and call upon me in time of need. There is no place in the universe that knows not my presence. I participate in all the affairs which those who are without call evil because their nature is not such as they approve. Every age has its own manager, who directs affairs according to my decrees. This office is changeable from generation to generation, that the ruler of this world and his chiefs may discharge the duties of their respective offices every one in his own turn. I allow everyone to follow the dictates of his own nature, but he that opposes me will regret it sorely. No god has a right to interfere in my affairs, and I have made it an imperative rule that everyone shall refrain from worshiping all gods. All the books of those who are without are altered by them; and they have declined from them, although they were written by the prophets and the apostles. That there are interpolations is seen in the fact that each sect endeavors to prove that the others are wrong and to destroy their books. To me truth and falsehood are known. When temptation comes, I give my covenant to him that trusts in me. Moreover, I give counsel to the skilled directors, for I have appointed them for periods that are known to me. I remember necessary affairs and execute them in due time. I teach and guide those who follow my instruction. If anyone obey me and conform to my commandments, he shall have joy, delight, and goodness.

\section{CHAPTER II}

I requite the descendants of Adam, and reward them with various rewards that I alone know. Moreover, power and dominion over all that is on earth, both that which is above and that which is beneath, are in my hand. I do not allow friendly association with other people, nor do I deprive them that are my own and that obey me of anything that is good for them. I place my affairs in the hands of those whom I have tried and who are in accord with my desires. I appear in divers manners to those who 
are faithful and under my command. I give and take away; I enrich and impoverish; I cause both happiness and misery. I do all this in keeping with the characteristics of each epoch. And none has a right to interfere with my management of affairs. Those who oppose me I afflict with disease; but my own shall not die like the sons of Adam that are without. None shall live in this world longer than the time set by me; and if I so desire, I send a person a second or a third time into this world or into some other by the transmigration of souls.

\section{CHAPTER III}

I lead to the straight path without a revealed book; I direct aright my beloved and my chosen ones by unseen means. All my teachings are easily applicable to all times and all conditions. I punish in another world all who do contrary to my will. Now the sons of Adam do not know the state of things that is to come. For this reason they fall into many errors. The beasts of the earth, the birds of heaven, and the fish of the sea are all under the control of my hands. All treasures and hidden things are known to me; and as I desire I take them from one and bestow them upon another. I reveal my wonders to those who seek them, and in due time my miracles to those who receive them from me. But those who are without are my adversaries, hence they oppose me. Nor do they know that such a course is against their own interests, for might, wealth, and riches are in my hand, and I bestow them upon every worthy descendant of Adam. Thus the government of the worlds, the transition of generations, and the changes of their directors are determined by me from the beginning.

\section{CHAPTER IV}

I will not give my rights to other gods. I have allowed the creation of four substances, four times, and four corners; because they are necessary things for creatures. The books of Jews, Christians, and Moslems, as of those who are without, accept in a sense, i. e., so far as they agree with, and conform to, my statutes. Whatsoever is contrary to these they have altered; do not accept it. Three things are against me, and I hate three things. But 
those who keep my secrets shall receive the fulfilment of my promises. Those who suffer for my sake I will surely reward in one of the worlds. It is my desire that all my followers shall unite in a bond of unity, lest those who are without prevail against them. Now, then, all ye who have followed my commandments and my teachings, reject all the teachings and sayings of such as are without. I have not taught these teachings, nor do they proceed from me. Do not mention my name nor my attributes, lest ye regret it; for ye do not know what those who are without may do.

\section{CHAPTER V}

$\mathrm{O}$ ye that have believed in me, honor my symbol and my image, for they remind you of me. Observe my laws and statutes. Obey my servants and listen to whatever they may dictate to you of the hidden things. Receive that that is dictated, and do not carry it before those who are without, Jews, Christians, Moslems, and others; for they know not the nature of my teaching. Do not give them your books, lest they alter them without your knowledge. Learn by heart the greater part of them, lest they be altered.

Thus endeth the book of Al-Jilwah, which is followed by the book of Maṣhaf Reš, i. e., the Black Book.

\section{MAȘḤAF REŠ (THE BLACK BOOK)}

In the beginning God created the White Pearl out of his most precious essence. $\mathrm{He}$ also created a bird named Angar. $\mathrm{He}$ placed the White Pearl on the back of the bird, and dwelt on it for forty thousand years. On the first day, Sunday, God created Melek Azazîl, and he is Țâ'us-Melek, the chief of all. On Monday he created Melek Dardâel, and he is Ših Hasan. Tuesday he created Melek Israfel, and he is Seih Sams [ad-Dîn]. Wednesday he created Melek Mihâel, and he is Šeih Abû Bakr. Thursday he created Melek Azrâel, and he is Sajad-ad-Dîn. Friday he created Melek Šemnâel, and he is Nașir-ad-Dîn. Saturday he created Melek Nurâel, and he is Yadin [Fahr-ad-Dîn]. And he made Melek Ṭâ'us ruler over all. ${ }^{55}$

After this God made the form of the seven heavens, the earth, the sun, and the moon. But Fahrr-ad-Din created man and the 
animals, and birds and beasts. He put them all in pockets of cloth, and came out of the Pear] accompanied by the angels. Then he shouted at the Pearl with a loud voice. Thereupon the White Pearl broke up into four pieces, and from its midst came out the water which became an ocean. The world was round, and was not divided. Then he created Gabriel and the image of the bird. $\mathrm{He}$ sent Gabriel to set the four corners. He also made a vessel and descended in it for thirty thousand years. After this he came and dwelt in Mount Lališ. Then he cried out at the world, and the sea became solidified and the land appeared, but it began to shake. At this time he commanded Gabriel to bring two pieces of the White Pearl; one he placed beneath the earth, the other stayed at the gate of heaven. He then placed in them the sun and the moon; and from the scattered pieces of the White Pearl he created the stars which he hung in heaven as ornaments. He also created fruit-bearing trees and plants and mountains for ornaments to the earth. He created the throne over the carpet. ${ }^{56}$ Then the Great God said: "O Angels, I will create Adam and Eve; and from the essence of Adam shall proceed Šehar bn Jebr, and of him a separate community shall appear upon the earth, that of Azazill, i. e., that of Melek Tầ'us, which is the sect of the Yezidis. Then he sent Šeih 'Adî bn Musâfir from the land of Syria, and he came [and dwelt in Mount] Lališ. Then the Lord came down to the Black Mountain. Shouting, he created thirty thousand Meleks, and divided them into three divisions. They worshiped him for forty thousand years, when he delivered them to Melek Tâ'us, who went up with them to heaven. At this time the Lord came down to the Holy Land (al-Kuds), and commanded Gabriel to bring earth from the four corners of the world, earth, air, fire, and water. He created it and put in it the spirit of his own power, and called it Adam.

Then he commanded Gabriel to escort Adam into Paradise, and to tell him that he could eat from all the trees but not of wheat. $^{57}$ Here Adam remained for a hundred years. Thereupon, Melek Tấus asked God how Adam could multiply and have descendants if he were forbidden to eat of the grain. God answered, "I have put the whole matter into thy hands." There- 
upon Melek Ṭ̂a'us visited Adam and said, "Have you eaten of the grain?" He answered, "No, God forbade me." Melek Tấ'us replied and said, "Eat of the grain and all shall go better with thee." Then Adam ate of the grain and immediately his belly was inflated. But Melek Ṭ̂a'us drove him out of the garden, and leaving him, ascended into heaven. Now Adam was troubled because his belly was inflated, for he had no outlet. God therefore sent a bird to him which pecked at his anus and made an outlet, and Adam was relieved.

Now Gabriel was away from Adam for a hundred years. And Adam was sad and weeping. Then God commanded Gabriel to create Eve from under the left shoulder of Adam. Now it came to pass, after the creation of Eve and of all the animals, that Adam and Eve quarreled over the question whether the human race should be descended from him or from her, for each wished to be the sole begetter of the race. This quarrel originated in their observation of the fact that among animals both the male and the female were factors in the production of their respective species. After a long discussion Adam and Eve agreed on this: each should cast his seed into a jar, close it, and seal it with his own seal, and wait for nine months. When they opened the jars at the completion of this period, they found in Adam's jar two children, male and female. Now from these two our sect, the Yezidis, are descended. In Eve's jar they found naught but rotten worms emitting a foul odor. And God caused nipples to grow for Adam that he might suckle the children that proceeded from his jar. This is the reason why man has nipples.

After this Adam knew Eve, and she bore two children, male and female; and from these the Jews, the Christians, the Moslems, and other nations and sects are descended. But our first fathers are Šeth, Noah, and Enosh, the righteous ones, who were descended from Adam only.

It came to pass that trouble arose between a man and his wife, resulting from the denial on the part of the woman that the man was her husband. The man persisted in his claim that she was his wife. The trouble between the two was settled, however, through one of the righteous men of our sect, who decreed that at 
every wedding a drum and a pipe should be played as a testimony to the fact that such a man and such a woman were married legally.

Then Melek Tâ'us came down to earth for our sect [i. e., the Yezidis], the created ones, and appointed kings for us, besides the kings of ancient Assyria, Nisroch, who is Nașir-ad-Dîn; Kamush, who is Melek Fabr-ad-Din, and Artâmîs, who is Melek Šams-[ad-]Dîn. After this we had two kings, Šabur (Sapor) First (224-272 A. D.) and Second (309-379), who reigned one hundred and fifty years; and our amirs down to the present day have been descended from their seed. But we hated four kings.

Before Christ came into this world our religion was paganism. King Ahab was from among us. And the god of Ahab was called Beelzebub. Nowadays we call him Pir Bub. We had a king in Babylon, whose name was Bahntnașar; another in Persia, whose name was Aḥšuraš; and still another in Constantinople, whose name was Agrikâlus. The Jews, the Christians, the Moslems, and even the Persians, fought us; but they failed to subdue us, for in the strength of the Lord we prevailed against them. He teaches us the first and last science. And of his teachings is:

Before heaven and earth existed, God was on the sea, as we formerly wrote you. He made himself a vessel and traveled in it in kunsiniyat ${ }^{58}$ of the seas, thus enjoying himself in himself. $\mathrm{He}$ then created the White Pearl and ruled over it for forty years. Afterward, growing angry at the Pearl, he kicked it; and it was a great surprise to see the mountains formed out of its cry; the hills out of its wonders; the heavens out of its smoke. Then God ascended to heaven, solidified it, established it without pillars. He then spat upon the ground, and taking a pen in hand, began to write a narrative of all the creation.

In the beginning he created six gods from himself and from his light, and their creation was as one lights a light from another light. And God said, "Now I have created the heavens; let some one of you go up and create something therein." Thereupon the second god ascended and created the sun; the third, the moon; the fourth, the vault of heaven; the fifth, the $\operatorname{far} \dot{g}$ (i. e., the morning star); the sixth, paradise; the seventh, hell. We have already told you that after this they created Adam and Eve. 
And know that besides the flood of Noah, there was another flood in this world. Now our sect, the Yezidis, are descended from $\mathrm{Na}$ umi, an honored person, king of peace. We call him Melek Miran. The other sects are descended from Ham, who despised his father. The ship rested at a village called 'Ain Sifni, ${ }^{59}$ distant from Mosul about five parasangs. The cause of the first flood was the mockery of those who were without, Jews, Christians, Moslems, and others descended from Adam and Eve. We, on the other hand, are descended from Adam only, as already indicated. This second flood came upon our sect, the Yezidis. As the water rose and the ship floated, it came above Mount Sinjar, ${ }^{60}$ where it ran aground and was pierced by a rock. The serpent twisted itself like a cake and stopped the hole. Then the ship moved on and rested on Mount Judie.

Now the species of the serpent increased, and began to bite man and animal. It was finally caught and burned, and from its ashes fleas were created. From the time of the flood until now are seven thousand years. In every thousand years one of the seven gods descends to establish rules, statutes, and laws, after which he returns to his abode. While below, he sojourns with us, for we have every kind of holy places. This last time the god dwelt among us longer than any of the other gods who came before him. He confirmed the saints. He spoke in the Kurdish language. He also illuminated Mohammed, the prophet of the Ishmaelites, who had a servant named Mu'âwiya. When God saw that Mohammed was not upright before him, he afflicted him with a headache. The prophet then asked his servant to shave his head, for Mu'âwiya knew how to shave. He shaved his master in haste, and with some difficulty. As a result, he cut his head and made it bleed. Fearing that the blood might drop to the ground, Mu'âwiya licked it with his tongue. Whereupon Mohammed asked, "What are you doing, Mu'âwiya?" He replied, "I licked thy blood with my tongue, for I feared that it might drop to the ground." Then Mohammed said to him, "You have sinned, O Mu'âwiya, you shall draw a nation after you. You shall oppose my sect." Mu'âwiya answered and said, "Then I will not enter the world; I will not marry." 
It came to pass that after some time God sent scorpions upon Mu'âwiya, which bit him, causing his face to break out with poisøn. Physicians urged him to marry lest he die. Hearing this, he consented. They brought him an old woman, eighty years of age, in order that no child might be born. Mu'âwiya knew his wife, and in the morning she appeared a woman of twenty-five, by the power of the great God. And she conceived and bore our god Yezid. But the foreign sects, ignorant of this fact, say that our god came from heaven, despised and driven out by the great God. For this reason they blaspheme him. In this they have erred. But we, the Yezidi sect, believe this not, for we know that he is one of the above-mentioned seven gods. We know the form of his person and his image. It is the form of a cock which we possess. None of us is allowed to utter his name, nor anything that resembles it, such as šeitân (Satan), ḳaitân (cord), šar (evil), šat (river), and the like. Nor do we pronounce mal'ûn (accursed), or la anat (curse), or $n a^{2} a l^{61}$ (horseshoe), or any word that has a similar sound. All these are forbidden us out of respect for him. So hass (lettuce) is debarred. We do not eat it, for it sounds like the name of our prophetess Hassiah. Fish is prohibited, in honor of Jonah the prophet. Likewise deer, for deer are the sheep of one of our prophets. The peacock is forbidden to our Seih and his disciples, for the sake of our Tâ'us. Squash also is debarred. It is forbidden to pass water while standing, or to dress up while sitting down, or to go to the toilet room, or to take a bath according to the custom of the people. ${ }^{62}$ Whosoever does contrary to this is an infidel. Now the other sects, Jews, Christians, Moslems, and others, know not these things, because they dislike Melek Țâ'us. $\mathrm{He}$, therefore, does not teach them, nor does he visit them. But he dwelt among us; he delivered to us the doctrines, the rules, and the traditions, all of which have become an inheritance, handed down from father to son. After this, Melek Tấus returned to heaven.

One of the seven gods made the sanjaks ${ }^{63}$ (standards) and gave them to Solomon the wise. After his death our kings received them. And when our god, the barbarian Yezîd, ${ }^{64}$ was born, he 
received these sanjaks with great reverence, and bestowed them upon our sect. Moreover, he composed two songs in the Kurdish language to be sung before the sanjaks in this language, which is the most ancient and acceptable one. The meaning of the song is this:

Hallelujah to the jealous God.

As they sing it, they march before the sanjaks with timbrels and pipes. These sanjaks remain with our emir, who sits on the throne of Yezîd. When these are sent away, the kawwâls assemble with the emir, and the great general, the seih, who is the representative of Šeib Nașir ad-Dín, i. e., Nisroch, god of the ancient Assyrians. They visit the sanjaks. Then they send each sanjak in care of a kawwâl to its own place; one to Halataneye, one to Aleppo, one to Russia, and one to Sinjar. These sanjaks are given to four kawwâls by contract. Before they are sent, they are brought to Šeib 'Adî's tomb, where they are baptized amid great singing and dancing. After this each of the contractors takes a load of dust from Šeib 'Adî's tomb. He fashions it into small balls, each about the size of a gall nut, and carries them along with the sanjaks to give them away as blessings. When he approaches a town, he sends a crier before him to prepare the people to accept the kawwâl and his sanjak with respect and honor. All turn out in fine clothes, carrying incense. The women shout, and all together sing joyful songs. The kawwâl is entertained by the people with whom he stops. The rest give him silver presents, everyone according to his means.

Besides these four sanjaks, there are three others, seven in all. These three are kept in a sacred place for purposes of healing. Two of them, however, remain with Seib 'Adî, and the third remains in the village of Bahazanie, which is distant from Mosul about four hours. Every four months these kawwâls travel about. One of them must travel in the province of the emir. They travel in a fixed order, differing each year. Every time he goes out, the traveler must cleanse himself with water made sour with summak (sumac) and anoint himself with an oil. He must also light a lamp at each idol that has a chamber This is the law that pertains to the sanjaks. 
The first day. of our new year is called the Sersâlie, i. e., the beginning of a year. It falls on the Wednesday of the first week in April. ${ }^{65}$ On that day there must be meat in every family. The wealthy must slaughter a lamb or an ox; the poor must kill a chicken or something else. These should be cooked on the night the morning of which is Wednesday, New Year's day. With the break of day the food should be blessed. On the first day of the year, alms should be given at tombs where the souls of the dead lie.

Now the girls, large and small, are to gather from the fields flowers of every kind that have a reddish color. They are to make them into bundles, and, after keeping them three days, they are to hang them on the doors ${ }^{66}$ as a sign of the baptism of the people living in the houses. In the morning all doors will be seen well decorated with red lilies. But women are to feed the poor and needy who pass by and have no food; this is to be done at the graves. But as to the kawwâls, they are to go around the tombs with timbrels, singing in the Kurdish language. For so doing they are entitled to money. On the above-mentioned day of Serșâlie no instruments of joy are to be played, because God is sitting on the throne (arranging decrees for the year), ${ }^{67}$ and commanding all the wise and the neighbors to come to him. And when he tells them that he will come down to earth with song and praise, all arise and rejoice before him and throw upon each other the squash of the feast. Then God seals them with his own seal. And the great God gives a sealed decision to the god who is to come down. He, moreover, grants him power to do all things according to his own will. God prefers doing good and charity to fasting and praying. The worship of any idol, such as Seyedad-Dîn or Šinh Sams is better than fasting. Some layman is to give a banquet to a kôchak after the fasting of the latter 40 days, whether it be in summer or in winter. If he (the kôchak) says this entertainment is an alms given to the sanjak, then he is not released from his fasting. When it comes to pass that the yearly tithe-gatherer finds that the people have not fully paid their tithes, he whips them till they become sick, and some even die. The people are to give the kôchaks money to fight the Roman army, and thus save the sect (Yezidis) from the wrath of the man of the year. 
Every Friday a load of gifts is to be brought as an offering to an idol. At that time, a servant is to call the people aloud from the roof of a kôchak's house, saying, it is the call of the prophet to a feast. All are to listen reverently and respectfully; and, on hearing it, every one is to kiss the ground and the stone on which he happens to lean.

It is our law that no kawwâl shall pass a razor over his face. Our law regarding marriage is that at the time of the wedding a loaf of bread shall be taken from the house of a kôchak and be divided between the bride and the bridegroom, each to eat onehalf. They may, however, eat some dust from Seib 'Adî's tomb instead of the bread for a blessing. Marriage in the month of April is forbidden, for it is the first month of the year. This rule, however, does not apply to kawwâls; they may marry during this month. No layman is allowed to marry a kôchak's daughter. Every one is to take a wife from his own class. But our emir may have for a wife any one whom he pleases to love. A layman may marry between the ages of ten and eighty; he may take for a wife one woman after another for a period of one year. On her way to the house of the bridegroom, a bride must visit the shrine of every idol she may happen to pass; even if she pass a Christian church, she must do the same. On her arrival at the bridegroom's house, he must hit her with a small stone in token of the fact that she must be under his authority. Moreover, a loaf of bread must be broken over her head as a sign to her that she must love the poor and needy. No Yezidi may sleep with his wife on the night the morning of which is Wednesday, and the night the morning of which is Friday. Whosoever does contrary to this commandment is an infidel. If a man steal the wife of his neighbor, or his own former wife, or her sister or mother, he is not obliged to give her dowry, for she is the booty of his hand. Daughters may not inherit their father's wealth. A young lady may be sold as an acre of land is sold. If she refuses to be married, then she must redeem herself by paying her father a sum of money earned by her service and the labor of her hand.

Here ends Kitâb Reš, which is followed by several stories, some of which are told secretly, some openly. 


\section{APPENDIX}

They say our hearts are our books, and our šeibs tell us everything from the second Adam until now and the future. When they notice the sun rise, they kiss the place where the rays first fall; they do the same at sunset, where its rays last fall. Likewise they kiss the spot where the moon first casts its rays and where it last casts them. They think, moreover, that by the multiplication of presents to šeihs and idols they keep troubles and afflictions away.

There is a great difference among the kôchaks; they contradict one another. Some say, "Melek Tâ'us appears to me and reveals to me many revelations." Others say, "We appear to people in many different ways." Some believe that Christ is Ših Šams himself. They say that they have had prophets in all times; the kôchaks are the prophets, One of the kôchaks says in one of his prophecies: "I was in Jonah's ship, where a lot was cast in my presence. It. fell on Jonah; and he was thrown into the sea, where he remained forty days and nights." Another said: "I was sitting with the great God, who said ' $I$ hope the time will come when I shall send Christ to the world.' I said to him, 'Yes.' Then he sent him. After making a sign in the sun, Christ came down to the earth." He appeared to our sect only, and made for us seven circles, which are at Šeib "Adî. Now he appeared to us because we observe the necessary order, which the other sects do not observe. Their origin and race are unknown; ours are known. We are emirs and sons of emirs; we are šeibs and sons of šeibs; we are kôchaks and sons of kôchaks, etc. But Christians and Moslems make priests and mullas for themselves out of those who had none of their kindred in those offices before, and never will have afterward. We are better than they. We are allowed to drink wine; our young men also may desire it when they, in company with women, engage in religious dancing and playing. Some of the kôchaks and šeibs, however, are not allowed to drink it. When one is about to die, he is visited by a kôchak, who places a bit of Šeib 'Adî's dust in his mouth. Before he is buried his face is anointed with it. Moreover, the dung of sheep is placed on his tomb. Finally, food is offered on behalf of the dead. The kôchaks pray for the dead at the graves, for which 
service they are paid. They tell the relatives of the dead what they see in dreams and visions, and the condition of their dead, whether they have been translated to the human or to the animal race. Some people hide silver or gold coins that they plan to take out in case they are born the second time in this world. Some believe that the spirits of many righteous persons travel in the air. Those spirits make revelations to the kôchaks, who are acquainted with the world of mysteries and secrets. Life and death are in their hands. Hence the fate of the people depends on the gratitude and honor which they show the kôchaks. According to Yezidis, hell has no existence. It was created in the time of the first Adam, they say, when our father, Ibrîk al-Așfar, was born. ${ }^{68} \quad$ By reason of his generosity and noble deeds, Ibrîk had many friends. Now, when he viewed hell he became very sad. He had a small bakbu ulk asfar, ${ }^{69}$ into which, as he kept weeping, his tears fell. In seven years it was filled. He then cast it into hell, and all its fires were put out that mankind might not be tortured. This incident relates to one of the noble deeds of our first father, Ibrîk-al-Aṣfar. They have many more such upright men of noble deeds. Such an one is Mohammed Rašân, whose resting-place is behind the mount of Ših Mattie. ${ }^{70}$ He (Rašân) is exceedingly strong, so that the most sacred oaths are sworn by him. If any one becomes sick, he takes refuge in making vows to hasin, i. e., pillars of idols. Now there is a place of religious pilgrimage which is called Sitt Nafîsah. This place is a mulberry tree in the village of Ba ašika. Another such place is called 'Abdi Rašân, and is in the village of Karabek. A third place of pilgrimage is in the village of Bahzanie, which is called Šeib Bakû. Nearby is a spring, and beside this is a mulberry tree. Whoever is afflicted with fever, goes to that tree, hangs on its branches a piece of cloth from his clothes, and casts bread in the spring for the fish. All this he does that he may be cured. They entertain the belief that whoever unties or shakes off one of the shreds of cloth will catch the disease with which the man was aflicted when he hung it up. There are many such trees in the village of Ba'ašị̂a, and in some other places. There is also a spring of water, called in the common language 'Ain aṣ-Șafra (Yellow 
Spring). The Yezidis call it Kani-Zarr. ${ }^{11}$ In this swim those who are afflicted with the disease of $a b \hat{u}$-safar (jaundice). But those who are troubled with dropsy go for cure to the house of the Pir that lives in the village of Man Reš.

When they assemble at Šeih 'Adi's, no one is allowed to cook anything. Everyone is to eat from Š̉ih 'Adî's table. As to the kôchaks, every one of them sits on a stone, as one sits in prayer. To them the laity go, seeking succor. They give them money while making their petition, and vow to the stone on which the kôchak sits sheep and oxen, everyone according to his means. Now, at the New Year the places are given in contract. When they assemble at the New Year, they dance and play with instruments of joy. Before eating the kabdušs, i. e., the vowed ox, they swim in the water of Zamzam, a spring coming from beneath the temple of Seih 'Adî. Then they eat in haste, snatching meat from the pot like fanatics, so that their hands are frequently burned. This practice is in accordance with their rules. After eating, they go up the mountain, shooting with their guns, and then return to Seib 'Adî. Everyone of them takes a little dust and preserves it for the times of wedding and death. They wear entwined girdles which they call the ties of the back (belt). They baptize these and the sanjaks with the water of Zamzam. $\mathrm{He}$ who is called Jawis ${ }^{72}$ wears a stole which is woven from the hair of a goat. It is nine spans in length and around it are sansûls (tinsels).

When the gathering comes to an end, they collect the money from the kôchaks and the contractors, and bring it to the emir. After everyone has taken according to his rank, the remainder goes to the emir.

They have another gathering which takes place at the feast of Al-Hijâjj. At this pilgrimage they go up to the mountain which is called Jabal al- Arafât. $^{73}$ After remaining there an hour, they hasten toward Seib 'Adî. He who arrives there before his companions is praised much. Hence everyone tries to excel. The one who succeeds receives abundant blessings.

They still have another assembly. This is called "the road of the kôchaks," when each, putting a rope around his neck, goes up 
the mountain. After collecting wood they bring it to Šeih 'Adî, carrying it on their backs. The wood is used for heating purposes and for the emir's cooking.

During these assemblies the sanjaḳs are passed around. In the first place they are washed with water made sour with sumac in order to be cleansed from their rust. The water is given away in drinks for purposes of blessing. In return money is taken. In the second place, the kôchaks go around with the sanjaks to collect money.

In their preaching, the šeibs tell the people that all kings have come from their descent, such as Nisroch, ${ }^{74}$ who is Nasr-ad-Dîn, and Kamuš who is Fabr ad-Dîn, and Artâmîs, who is Šams adDîn, and many others, as Shabur and Yoram; and many royal names of the ancient kings, together with their own (Yezidi) kings, are from their seed. The sign of the Yezidi is that he wears a shirt with a round bosom. It differs from that of the other people, the bosom of whose shirts are open all the way down.

There is one occasion when no Yezidi will swear falsely, viz., when one draws a circle on the ground, and tells him that this circle belongs to Tấus-Melek, Šeih 'Adî, and Yezîd, and baryshabakei. ${ }^{\text {i5 }} \mathrm{He}$ places him in the middle of the circle, and then tells him that Melek Tấ'us and all those who were mentioned above will not intercede for him after his death, and that the shirt of the Jewish Nasim ${ }^{76}$ be on his neck, and that the hand of Nasim be on his neck and eye, and that Nasim be his brother for the next world, and let him be to him for a šeib and a pir if he dỏes not tell the truth. Then if he swears to tell the truth, he cannot conceal anything. For an oath made under such conditions is considered greater than that made in the name of God, and even than that made in the name of one of their prophets.

They fast three days in a year from morning till evening. The fast falls in December, according to the oriental calendar. They have no prayer ${ }^{77}$ except what is mentioned above, such as that referring to the sun and the moon, and asking help from seibs and holy places when they say, "O Šeib "Adî, O Šib Sams," and the like. They are all forbidden to teach their children anything, 
with the exception of two stanzas which they teach their children out of necessity and because it is traditional.

A story is told about them by reliable people. Once when Seib Nașir was preaching in a village at Mount Sinjar, there was a Christian mason in the audience who, seeing the house filled with people, thought they were going to pray. He then pretended to take a nap, that he might amuse himself with what he should hear. He knew the Kurdish language. When the Christian seemed to be asleep, but was really awake and listening, Šeib Nașir began to preach saying: "Once the great God appeared to me in vision. He was angry at Jesus because of a dispute with him. He therefore caught him and imprisoned him in a den which had no water. Before the mouth of the den he placed a great stone. Jesus remained in the den a long time, calling upon the prophets and the saints for help and asking their aid. Every one whose succor Jesus asked went to beg the great God to release him. But God did not grant their requests. Jesus therefore remained in a sorrowful state, knowing not what to do." After this the preacher remained silent for a quarter of an hour, and thus a great silence prevailed in the house. Then he went on to say: "O poor Jesus, why are you so forgotten, so neglected? Do you not know that all the prophets and all the saints have no favor with the great God like unto Melek Tâ'us? Why have you forgotten him and have not called upon him?" Saying this, the preacher again remained silent as before. Afterward he again continued: "Jesus remained in the den till one day when he happened to remember Melek Tấus. He then sought his aid, praying, ' $O$ Melek 'Tâ'us, I have been in this den for some time. I am imprisoned; I have sought the help of all the saints, and none of them could deliver me. Now, save me from this den.' When Melek Tâ'us heard this, he descended from heaven to earth quicker than the twinkling of an eye, removed the stone from the top of the den, and said to Jesus, 'Come up, behold I have brought thee out.' Then both went up to heaven. When the great God saw Jesus, he said to him, 'O Jesus, who brought thee out of the den? Who brought thee here without my permission?' Jesus answered and said, 'Melek Ṭâ'us brought me out of 
the den and up here.' Then God said, 'Had it been another, I would have punished him, but Melek Tâ'us is much beloved by me; remain here for the sake of my honor.' So Jesus remained in heaven." The preacher added, "Notice that those who are without do not like Melek Tấus. Know ye that in the resurrection he will not like them either, and he will not intercede for them. But, as for us, he will put us all in a tray, carry us upon his head, and take us into heaven, while we are in the tray on his head." When the congregation heard this, they rose up, kissed his clothes and feet, and received his blessing.

Now the views of the Yezidis regarding the birth of Christ and the explanation of the name of the Apostle Peter, are found in one of their stories, which runs thus: "Verily Mary the Virgin mother of Jesus, begat Jesus in a manner unlike the rest of women. She begat him from her right side,$^{78}$ between her clothes and her body. At that time the Jews had a custom that, if a woman gave birth, all her relatives and neighbors would bring her presents. The women would call, carrying in their right hand a plate of fruits which were to be found in that season, and in the left hand they would carry a stone. This custom was a very ancient one. Therefore when Mary the Virgin gave birth to Jesus, the wife of Jonah, who is the mother of Peter, came to her; and, according to the custom, carried a plate of fruit in her right hand and a stone in her left. As she entered and gave Mary the plate, behold, the stone which was in her left hand begat a male. She called his name Simon Cifa, that is, son of the stone. Christians do not know these things as we do."

They have a story explaining the word heretic. It is this: When the great God created the heavens, he put all the keys of the treasuries and the mansions therein in the hands of Melek Tâ'us, and commanded him not to open a certain mansion. But he, without the knowledge of God, opened the house and found a piece of paper on which was written, "Thou shalt worship thy God alone, and him alone shalt thou serve." He kept the paper with him and allowed no one else to know about it. Then God created an iron ring and hung it in the air between the heaven and the earth. Afterward he created Adam the first. Melek 
Tấ'us refused to worship Adam when God commanded him to do so. He showed the written paper which he took from the mansion and said, "See what is written here." Then the great God said, "It may be that you have opened the mansion which I forbade you to open." He answered, "Yes." Then God said to him, "You are a heretic, because you have disobeyed me and transgressed my commandment."

From this we know that God speaks in the Kurdish language, that is, from the meaning of this saying, "Go into the iron ring which I, thy God, have made for whosoever does contrary to my commandment and disobeys me."

When one criticizes such a story as this by saying that God drove Melek Tấ'us from heaven and sent him to hell because of his pride before God the most high, they do not admit that such is the case. They answer: "Is it possible that one of us in his anger should drive out his child from his house and let him wait until the next day before bringing him back? Of course not. Similar is the relation of the great God to Melek Tâ'us. Verily he loves him exceedingly. You do not understand the books which you read. The Gospel says, 'No one ascended up to heaven but he who came down from heaven.' No one came down from heaven but Melek Tấ'us and Christ. From this we know that the great God has been reconciled to Melek Tấ'us, who went up to heaven, just as Christ came down from heaven and went up again."

The following is a story told of a kôchak: It is related that at one time there was no rain in the village of Baašîna. In this village there was a Yezidi whose name was Kôchak Berû. There were also some saints and men of vision dwelling there. They (people) gathered to ask Berû to see about the rain. He told them, "Wait till tomorrow that I may see about it." They came to him on the next day and said, "What have you done concerning the question of rain? We are exceedingly alarmed by reason of its being withheld." He answered: "I went up to heaven last night and entered into the divan where the great God, Šeih 'Adî, and some other šeibs and righteous men were sitting. The priest Isaac was sitting beside God. The great God said to me, 'What 
do you want, O Kôchak Berû; why have you come here?' I said to him, 'My lord, this year the rain has been withheld from us till now, and all thy servants are poor and needy. We beseech thee to send us rain as thy wont.' He remained silent and answered me not. I repeated the speech twice and thrice, beseeching him. Then I turned to the šeihs who sat there, asking their help and intercession. The great God answered me, 'Go away until we think it over.' I came down and do not know what took place after I descended from heaven. You may go to the priest Isaac and ask him what was said after I came down." They went to the priest and told him the story, and asked him what was said after Kôchak Berû came down. This priest Isaac was a great joker. He answered them, "After the kôchak came down, I begged God for rain on your behalf. It was agreed that after six or seven days he would send it." They waited accordingly, and by a strange coincidence, at the end of the period it rained like a flood for some time. Seeing this, the people believed in what they were told, and honored the priest Isaac, looking upon him as one of the saints, and thinking that he must have Yezidi blood in him. For more than twenty years this story has been told as one of the tales of their saints.

Once Šeih 'Adî bn Musâfir and his murids were entertained by God in heaven. When they arrived, they did not find straw for their animals. Therefore Šeib 'Adî ordered his murids to carry straw from his threshing floor on the earth. As it was being transported, some fell on the way, and has remained as a sign in heaven unto our day. It is known as the road of the straw man.

They think that prayer is in the heart; therefore they do not teach their children about it. And in their books neither is there any rule regarding prayer, nor is prayer considered a religious obligation.

Some assert that at one time Seih 'Adî, in company with Šin 'Abd-al-Ḳâdir, made a pilgrimage to Mecca, where he remained four years. After his absence Melek Ṭâ'us appeared to them (the two šeihs) in his symbol. He dictated some rules to them and taught them many things. Then he was hidden from them. Four 
years later Šeib 'Adî returned from Mecca; but they refused him and would not accept him. They asserted that he had died or ascended to heaven. He remained with them, but was without his former respect. When the time of his death came, Melek Tâ'us appeared to them and declared, "This is Seib "Adî himself, honor him." Then they honored him and buried him with due veneration, and made his tomb a place of pilgrimage. In their estimation it is a more excellent spot than Mecca. Everyone is under obligation to visit it once a year at least; and, in addition to this, they give a sum of money through the šeibs to obtain satisfaction (that Šeih 'Adî may be pleased with them). Whoever does this not is disobedient.

Moreover, it is said that the reason why the pilgrimage to his tomb is regarded as excellent by us and by God is that in the resurrection Seib 'Adî will carry in a tray all the Yezidis upon his head and take them into paradise, without requiring them to give account or answer. Therefore they regard the pilgrimage to his tomb as a religious duty greater than the pilgrimage to Mecca.

There are some domes, huts, around the tomb of Šeib 'Adî. They are there for the purpose of receiving blessings from the tomb. And they are all attributed to the great Seibs, as the hut of "Abd-al-Kâdir-al-Jîlâní;" the hut of Seih Kadíb-al-Bân; the hut of Šeih Šams-ad-Dîn; the hut of Šeib Manșûr-al-Hallâj, and the hut of Ših Hasan-al-Bașrî. There are also some other huts. Each hut has a banner made of calico. It is a sign of conquest and victory.

Eating of deer's meat is forbidden them, they say, because the deer's eyes resemble the eyes of Seib 'Adî. Verily his virtues are well-known and his praiseworthy qualities are traditions handed down from generation to generation. He was the first to accept the Yezidi religion. He gave them the rules of the religious sect and founded the office of the šeib. In addition to this, he was renowned for his devotion and religious exercise. From Mount Lališ, he used to hear the preaching of 'Abd-al-Ḳâdir-al-Jîlâni in Bagdad. He used to draw a circle on the ground and say to the religious ones, "Whosoever wants to hear the preaching of 
Al-Jîlânî, leł him enter within this circle." The following custom, which we have, began with him: If we wish to swear to anyone, a šeih draws a circle, and he who is to take an oath, enters into it.

At one time, passing by a garden, Šeih 'Adî asked about lettuce; and, as no one answered, he said, "Huss" (hush). For this reason lettuce is forbidden and not eaten.

As regards fasting, they say about the month of Ramadân that it was dumb and deaf. Therefore, when God commanded the Moslems to fast, he likewise commanded the Yezidis, saying to them in the Kurdish language, "sese," meaning "three." The Mohammedans did not understand it; they took it for "se," "thirty." For this reason, they (Yezidis) fast three days. Moreover, they believe there are eating, drinking, and other earthly pleasures in the next world. ${ }^{80}$ Some hold that the rule of heaven is in God's hands, but the rule of the earth is in Seib 'Adî's hands. Being exceedingly beloved by God, he bestowed upon him according to 'Adî's desire.

They believe in the transmigration of souls. This is evinced by the fact that when the soul of Manșûr-al-Ḥallâj parted from his body when the Caliph of Bagdad killed him and cast his head into the water, his soul floated on the water. By a wonderful chance and a strange happening, the sister of the said Manșur went to fill her jar. The soul of her brother entered it. Without knowing what had happened, she came with it to the house. Being tired, she felt thirsty and drank from the jar. At that moment the soul of her brother entered her, but she did not perceive it until she became pregnant. She gave birth to a son who resembled Šeih Manșâr himself. He became her brother according to birth and her son according to imputation. The reason why they do not use drinking-vessels which have narrow mouths, or a net-like cover, is that when one drinks water from them they make a sound. When the head of Šib Manșûr was thrown into the water it gurgled. In his honor they do not use the small jars with narrow necks.

They assert that they expect a prophet who will come from Persia to annul the law of Mohammed and abrogate Islam. They 
believe that there are seven gods, and that each god administers the universe for ten thousand years; and that one of these gods is Lasiferos, the chief of the fallen angels, who bears also the name Melek Tâ'us. They make him a graven image after the form of a cock ${ }^{81}$ and worship it. They play the tambourine and dance before it to make it rejoice with them. They (ḳawwâls) travel within the Yezidis' villages to collect money, at which time they take it into the houses that it may bless and honor them. Some say that Šin 'Adî is a deity; others that he is like a Vizier to God. To him all things are referred. This is the Melek Tâ'us age. The ruling and administrative power is in his hands until the thousandth year. When the time comes to an end he will deliver the power to the next god to rule and administer until another thousand years shall be ended, and so on until the seventh god. And yet there is accord and love among these gods, and none is jealous of the one who may rule and administer the world for a period of ten thousand years. They have a book named Al Jilwah that they ascribe to Šeib 'Adî, and they suffer no one who is not one of them to read it.

Mention is made in some of their books that the First Cause is the Supreme God, who before he created this world, was enjoying himself over the seas $;^{82}$ and in his hand was a great White Pearl, with which he was playing. Then he resolved to cast it into the sea, and when he did so this world came into being.

Moreover, they think themselves not to be of the same seed from which the rest of mankind sprung, but that they are begotten of the son of Adam, who was born to Adam of his spittle. For this reason they imagine themselves nobler and more pleasing to the gods than others.

They say they have taken fasting and sacrifice from Islam; baptism from Christians; prohibition of foods from the Jews; their way of worship from the idolaters; dissimulation of doctrine from the Rafidis (Shi'ites); human sacrifice and transmigration from the pre-Islamic paganism of the Arabs and from the Sabians. They say that when the spirit of man goes forth from his body, it enters into another man if it be just; but if unjust, into an animal. 


\section{THE POEM IN PRAISE OF ŠEIH 'ADÎ}

\section{Peace Be unto Him}

1. My understanding surrounds the truth of things,

2. And my truth is mixed up in me,

3. And the truth of my descent is set forth by itself,

4. And when it was known it was altogether in me.

5. And all that are in the universe are under me,

6. And all the habitable parts and deserts,

7. And everything created is under me,

8. And I am the ruling power preceding all that exists.

9. And I am he that spoke a true saying,

10. And I am the just judge and the ruler of the earth.

11. And I am he that men worship in my glory,

12. Coming to me and kissing my feet.

13. And I am he that spread over the heavens their height.

14. And I am he that cried in the beginning.

15. And I am he that of myself revealeth all things,

17. And I am he to whom came the book of good tidings

18. From my Lord, who burneth the mountains.

19. And I am he to whom all created men come

20. In obedience to kiss my feet.

21. I bring forth fruit from the first juice of early youth

22. By my presence, and turn toward me my disciples.

23. And before this light the darkness of the morning cleared away.

24. I guide him that asketh for guidance.

25. I am he that caused Adam to dwell in Paradise

26. And Nimrod to inhabit a hot burning fire.

27. And I am he that guided Ahmed the Just,

28. And let him into my path and way.

29. And I am he unto whom all creatures

30. Come for my good purposes and gifts.

31. And I am he that visited all the heights,

32. And goodness and charity proceed from my mercy.

33. And I am he that made all hearts to fear

34. My purpose, and they magnify the majesty and power of my awfulness.

35. And I am he to whom the destroying lion came

36. Raging, and I shouted against him and he became stone.

37. And I am he to whom the serpent came,

38. And by my will I made him dust.

39. And I am he that struck the rock and made it tremble, 
40. And made to burst from its sides the sweetest of waters.

41. And I am he that sent down the certain truth;

42. For me is the book that comforteth the oppressed.

43. And I am he that judged justly,

44. And when I judged it was my right.

45. And I am he that made the springs ${ }^{83}$ to give water,

46. Sweeter and pleasanter than all waters.

47. And I am he that caused it to appear in my mercy,

48. And by my power I called it the pure.

49. And I am he to whom the Lord of heaven hath said,

50. Thou art the just Judge and Ruler of the earth.

51. And I am he that disclosed some of my wonders,

52. And some of my virtues are manifested in that which exists.

53. And I am he that caused the mountains to bow,

54. To move under me and at my will. ${ }^{84}$

55. And I am he before whose majesty the wild beasts cried;

56. They turned to me worshiping, and kissed my feet.

57. And I am 'Adî aš-Šâmî, the son of Musâfir.

58. Verily the All-Merciful has assigned unto me names,

59. The heavenly throne, and the seat, and the (seven) heavens, and the earth.

60. In the secret of my knowledge there is no God but me.

61. These things are subservient to my power.

62. O mine enemies, why do you deny me?

63. O men, deny me not, but submit.

64. In the day of judgment you will be happy in meeting me.

65. Who dies in my love, I will cast him

66. In the midst of Paradise, by my will and pleasure;

67. But he that dies unmindful of me

68. Will be thrown into torture in misery and affliction.

69. I say I am the only one and the exalted;

70. I create and make rich those whom I will.

71. Praise be to myself, for all things are by my will,

72. And the universe is lighted by some of my gifts.

73. I am the king that magnifies himself,

74. And all the riches of creation are at my bidding.

75. I have made known unto you, $\mathrm{O}$ people, some of my ways.

76. Who desireth me must forsake the world.

77. And I can also speak the true saying,

78. And the garden on high is for those who do my pleasure.

79. I sought the truth and became a confirming truth;

80. And by the like truth shall they, like myself, possess the highest place. 


\section{THE PRINCIPAL PRAYER OF THE YEZIDIS}

1. Amen, Amen, Amen!

2. Through the intermediation of Šams-ad-Dîn,

3. Fabr ad-Dîn, Nașir-ad-Dîn

4. Sajad ad-Dîn, Šeih Sin (Ḥusein),

5. Š̉eib Bakr, Kââir ar-Raḥmân.

6. Lord, thou art gracious, thou art merciful;

7. Thou art God, king of kings and lands,

8. King of joy and happiness,

9. King of good possession (eternal life).

10. From eternity thou art eternal.

11. Thou art the seat of luck (happiness) and life;

12. Thou art lord of grace and good luck.

13. Thou art king of jinns and human beings,

14. King of the holy men (saints),

15. Lord of terror and praise,

16. The abode of religious duty and praise,

17. Worthy of praise and thanks.

18. Lord! Protector in journeys,

19. Sovereign of the moon and of the darkness,

20. God of the sun and of the fire,

21. God of the great throne,

22. Lord of goodness.

23. Lord! No one knows how thou art.

24. Thou hast no beauty; thou hast no height.

25. Thou hast no going forth; thou hast no number.

26. Lord! Judge of kings and beggars,

27. Judge of society and of the world,

28. Thou hast revealed the repentance of Adam.

29. Lord, thou hast no house; thou hast no money;

30. Thou hast no wings, hast no feathers;

31. Thou hast no voice, thou hast no color.

32. Thou hast made us lucky and satisfied.

33. Thou hast created Jesus and Mary.

34. Lord, thou art gracious,

35. Merciful, faithful.

36. Thou art Lord; I am nothingness.

37. I am a fallen sinner,

38. A sinner by thee remembered.

39. Thou hast led us out of darkness into light.

40. Lord! My sin and my guilt,

41. Take them and remove them.

42. O God, O God, O God, Amen! 


\section{The American Journal of Semitic Languages}

They are divided into seven classes, and each class has functions peculiar to itself that cannot be discharged by any of the other classes. They are:

1. Seib. He is the servant of the tomb, and a descendant of Imam Hasan al-Bașrî. No one can give a legal decision or sign any document except the šeih who is the servant of Ših 'Adî's tomb. He has a sign by which he is distinguished from others. The sign is a belt which he puts on his body, and net-like gloves, which resemble the halters of camels. If he goes among his people, they bow down and pay him their respects. The šeihs sell a place in paradise to anyone who wishes to pay money.

2. Emir. The emirship specifically belongs to the descendants of Yezîd. They have a genealogical tree, preserved from their fathers and forefathers, which goes up to Yezîd himself. The emirs have charge of the temporal and governmental affairs, and have the right to say, "Do this and do not that."

3. Kawwâl. He has charge of tambourines and flutes and religious hymns.

4. Pîr. To him appertain the conduct of fasts, the breaking of fasts, and hair-dressing.

5. Kôchak. To him appertain the duties of religious instruction, and sepulture, and interpretation of dreams, i. e., prophecy.

6. Fakîr. To him appertain the duties of instruction of boys and girls in playing on the tambourines, in dancing and religious pleasure. He serves Šeib 'Adî.

7. Mulla. To him appertain the duties of instructing children. He guards the books and the mysteries of religion and attends to the affairs of the sect.

At one time (A. H. 1289; A. D. 1872), the Ottoman power wanted to draft from among them an army instead of taking the tax which was its due. They presented to the government all the rules that prevented them from complying. These all pertain to religion and are moral obligations upon them. They are as follows:

\section{Article I}

According to our Yezidi religion every member of our sect, whether big or little, girl or woman, must visit Melek Țâ'us three times a year, 
that is, first, from the beginning to the last of the month of April, Roman calendar; secondly, from the beginning to the end of the month of September; thirdly, from the beginning to the end of the month of November. If anyone visit not the image of Melek Tấ'us, he is an infidel.

\section{Article II}

If any member of our sect, big or little, visit not his highness Šeih 'Adî bn Musâfir-may God sanctify his mysteries! once a year, i. e., from the fifteenth to the twentieth of the month of September, Roman calendar, he is an infidel according to our religion.

\section{Article III}

Every member of our sect must visit the place of the sunrise every day when it appears, and there should not be Moslem, nor Christian, nor any one else in that place. If any one do this not, he is an infidel.

\section{Article IV}

Every member of our sect must daily kiss the hand of his brother, his brother of the next world, namely, the servant of the Mahdi, and the hand of his šeib or pîr. If any one do this not, he is regarded as an infidel.

\section{Article V}

According to our religion it is something intolerable when the Moslem in the morning begins to say in prayer, God forbid! "I take refuge in God, etc." ${ }^{85}$ If any one of us hear it, he must kill the one who says it and kill himself; otherwise he becomes an infidel.

\section{Article VI}

When one of our sect is on the point of death, if there be no brother of the next world and his šeib, or his pir and one of the kawwals with him to say three sayings over him, viz.: "O servant of Melek Țâ'us, whose ways are high, you must die in the religion of the one we worship, who is Melek Țâ'us, whose ways are high, and do not die in any other religion than his. And if some one should come and say to you something from the Mohammedan religion, or Christian religion, or Jewish religion, or some other religion, do not believe him, and do not follow him. And if you believe and follow another religion than that of the one we worship, Melek Ṭâ'us, you shall die an infidel," he becomes an infidel.

\section{Article VII}

We have something called the blessing of Šeib 'Adî, that is, the dust of the tomb of Šeih 'Adí-may God sanctify his mystery! Every member of our sect must have some of it with him in his pocket and eat of it every morning. And if he eat not of it intentionally, he is an infidel. Likewise 


\section{The American Journal of Semitic Languages}

at the time of death, if he possess not some of that dust intentionally, he dies an infidel.

\section{Article VIII}

Regarding our fasting, if any one of our sect wish to fast, he must fast in his own place, not in another. For while fasting he must go every morning to the house of his šeib and his pir , and there he must begin to fast; and when he breaks his fast, likewise, he must go to the house of his šeib and his pir, and there break the fast by drinking the holy wine of the šeib or the pir. And if he drink not two or three glasses of that wine, his fasting is not acceptable, and he becomes an infidel.

\section{Article IX}

If one of our sect go to another place and remain there as much as one year, and afterward return to his place, then his wife is forbidden him, and none of us will give him a wife. If anyone give him a wife, that one is an infidel.

\section{Article X}

Regarding our dress, as we have mentioned in the fourth Article that every one of our sect has a brother for the next world, he has also a sister for the next world ${ }^{86}$ Therefore if any one of us make for himself a new shirt, it is necessary that his sister for the next world should open its neck band, i.e., the neck band of that shirt, with her hand. And if she open it not with her hand, and he wear it, then he is an infidel.

\section{Article XI}

If some one of our sect make a shirt or a new dress, he cannot wear it without baptizing it in the blessed water which is to be found at the shrine of his highness Seih 'Adi--may God sanctify his mystery! If he wear it, he is an infidel.

\section{Article XII}

We may not wear a light black dress at all. We may not comb our heads with the comb of a Moslem or a Christian or a Jew or any other. Nor may we shave our heads with the razor used by any other than ourselves (Yezidis), except it be washed in the blessed water which is to be found at the shrine of his highness Šeih 'Adî. Then it is lawful for us to shave our heads. But if we shave our heads without the razor having been washed in that water, we become infidels.

\section{Article XIII}

No Yezidi may enter the water-closet of a Moslem, or take a bath at a Moslem's house, or eat with a Moslem spoon, or drink from a Moslem's cup, from a cup used by any one of another sect. If he does, he is an infidel $^{87}$ 
Article XIV

Concerning food, there is a great difference between us and the other sects. We do not eat meat of fish, squash, bamia (okra), fasulia (beans), cabbage, or lettuce. We cannot even dwell in the place where lettuce is sown. ${ }^{88}$

For these and other reasons, we cannot enter the military service, etc.

The names of those who affixed their signatures:

The Head of the Yezidi Sect, the Emir of Šreibân, HusEin.

The Religious Šeib of the Yezidi Sect of the District of Š́ EIBÂn, Š́ EIH NAṣiR.

The Chief Š eig of the Village of Mam Rešîn, Pîr Suleiman.

The Village Chief of Muskân, Murad.

\begin{tabular}{|c|c|c|c|}
\hline 6 & "6 & "6 & 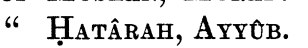 \\
\hline “ & “ & " & “ Beibân, Ḥusein. \\
\hline “ & " & " & “" DaHḲ̂AN, Ḥ̂ASSAN. \\
\hline “ & " & " & " ḤUZzân, NU'Mô. \\
\hline “ & “ & “ & " Bâkasra, 'Ali. \\
\hline “ & " & " & “ BẦAŠî̄ṬA, JAMÔ. \\
\hline “ & “ & “ & “ Ḥ̂̂ššâBa, ILIAS. \\
\hline “ & " & " & " KREPAHin, Sä́d. \\
\hline “ & “ & “ & “ Ḳ̂AÂREH, Ко̂CHaK. \\
\hline “ & “ & “ & KaSô. \\
\hline “ & “ & “ & “ Sinâ, 'ABdô. \\
\hline “ & " & “ & " 'Ain Sifni, Gurgô. \\
\hline “ & “ & “ & “ ḲASR-' $_{\text {AzZ-AD-Dîn. }}$ \\
\hline “ & “ & " & " Heirô. \\
\hline “ & " & “ & “ KIBERTô, Ṭ̂̂HIR. \\
\hline
\end{tabular}

AND OTHERS.

These are they whose names were in the petition above mentioned, and from which we copied a few things.

The result was that when they presented this petition, they were exempted from military service, but they paid a tax in money as did the Christians.

\section{NOTES}

1. Al-Jilwah is said to have been written in 558 A. н., by Šeib Fabrad-Din, the secretary of Šeib 'Âdî, at the dictation of the latter. The original copy, wrapped in linen and silk wrappings, is kept in the house of Mulla Ḥaidar, of Baadrie. Twice a year the book is taken to Šeih 'Adî's shrine. (Letter from Šammas Jeremia Šamir to Mr. A. N. Andrus, of Mardin, dated October 28, 1892.) 


\section{The American Journal of Semitic Languages}

2. The Black Book is said to have been written by a certain Hasan al-Bașrî, in 743 A. н. The original copy is kept in the house of Kehyah (chief) 'Ali, of Kasr 'Az-ad-Dîn, one hour west of Semale, a village east of Tigris. The book rests upon a throne, having over it a thin covering of red broadcloth, of linen, and other wrappings. Then is disclosed the

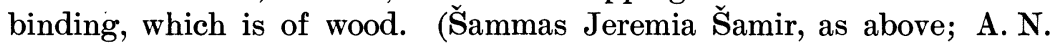
Andrus, letter, dated November 9, 1901.)

3. The exact number of the Yezidis is unknown. See also Societé de Géographie de l'Est, Bulletin, 1903, p. 284; Al Mašrik, II, 834.

4. For a fuller account of the literature on the Yezidis, consult $\mathrm{J}$. Menant, Les Yézidis, and Paul Perdrizet, Société de Géographie de l'Est, Bulletin, 1903, pp. $281 \mathrm{ff}$.

5. Société de Géographie de l'Est,. Bulletin, 1903, p. 297.

6. Fraser, Mesopotamia and Persia, pp. 285, 287; Rich, Residence in Kurdistan, II, 69; Al Mašrik, II, 396; Badger, The Nestorians and their Rituals, I, 111; Assemani, Bibliotheca Orientalis, III, 439.

7. Michel Febvre, Théâtre de la Turquie, p. 364; Société de Géographie de l'Est, Bulletin, 1903, pp. 299, 301; cf. also J. Menant, Les Yezidis, pp. 52, 86, 132.

8. Oppenheim, Vom Mittelmeer zum persischen Golf, 1900, II, 148; Victor Dingelstedt, Scottish Geographical Magazine, XIV, 295; Southgate, A Tour through Armenia, II, 317; A. V. Williams Jackson, "Yezidis," in the New International Encyclopedia, XVII, 939; Perdrizet, loc. cit., p. 299.

9. A. V. Williams Jackson, Persia Past and Present, p. 10, New International Encyclopedia, "Yezidis;" Perdrizet, loc. cit.

10. Dingelstedt, loc. cit.; Revue de l'Orient Chrétien, I, "Kurdistan."

11. Société de Géographie de l'Est, loc. cit.; Encyclopedia of Missions, "Yezidis;" A. V. Williams Jackson, loc. cit.

12. On these sects consult Aš-Šahrastânî, I, 86, 89, 100.

13. Not like Mohammed, to whom, according to Moslem belief, the Koran was revealed at intervals.

14. On the Sabians of the Koran, see Baiḍâwi and Zamabšari on Suras 2,$59 ; 5,73 ; 22,17$.

15. On the Sabians of Harrân see Fihrist, p. 190; on the Șabians in general consult Aš-Šahrastânî, II, 203; on the location of Ḥarrân and Wasit, see Yaḳat, II, 331, and IV, 881.

16. To get more particular information in regard to Yezîd bn Unaisa, I wrote to Mosul, Bagdad, and Cairo, the three centers of Mohammedan learning, and strange to say, none could throw any light on the subject.

17. Al-Ḥaratiyah he describes as Aṣhâab Al-Ḥareț (I, 101), al-Ḥafaẓiyah, Aṣhâb Ḥafez (ibid.), etc. 
18. Ibn Hallikân says: "Aš-Šahrastânî, a dogmatic theologian of the Ašarite sect, was distinguished as an Imâm and a doctor of the law. He displayed the highest abilities as a jurisconsult. The Kitâb al-Milal $w a-n$-Nihal (this is the book in which Aš-Šahrastâni traces the Yezidi sect to Yezîd bn Unaisa) is one of his works on scholastic theology. He remained without an equal in that branch of science."

19. It is to be noticed also that the name "Unaisa" is very common among the Arabs; cf. Ibn Sa'ad (ed. Sachau), III, 254, 260, 264, 265, 281, 283, 287, 289; Musnad, VI, 434; Mishkat, 22, 724.

20. Professor C. C. Torrey, of Yale University, kindly examined the manuscript on this point.

21. Geschichte der herrschenden Ideen des Islams, p. 195.

22. Ibn Hallikân (Egyptian edit., A. н. 1310), I, 316; Mohammed al'Omari, al-Maușili, and Yâsîn al-Hâtib al-'Omari al-Mauṣili, "Š́eib 'Adî," quoted by M. N. Siouff, Journal asiatique, 1885, 80; Yakut, IV, 374.

23. 'Itikad Ahl as-Sunna, "Belief of the Sunnites," the Wasaya, "Counsels to the Califs;" cf. C. Huart, History of Arabic Literature, p. 273.

24. See p. 239 of this paper.

25. Aš-Š́ahrastânî regards them a Harijite sub-sect.

26. Layard, Nineveh and its Remains, II, 254.

27. Mohammed al-' Omari al-Maușili and Yâsîn al-Hâtib al-' Omari alMaușili, "Šeib 'Adî," quoted by M. N. Siouffi, Journal asiatique, Série viii, V (1885), 80.

28. George Warda, Bishop of Arbila, Poems, edited by Heinrich Hilgenfeld, Leipzig, 1904.

29. Such as their ceremonies at Šeih 'Adî (Badger, The Nestorians, I, 117), which have obtained for them the name Cherag Sonderan, "The Extinguishers of Light." Bar Hebraeus (Chronicon Eccles., ed. Abeloos-Lamy, I, 219) speaks of similar practices among what he calls "Borborians," a branch of the Manichaeans, and calls them مكبري L eastern sects also; see Abhandlungen für die Kunde des Morgenlandes, $\mathrm{V}, 124$.

30. Professor Jackson, of Columbia University, seems to trace it to the "old devil-worship in Mazanderan" (JAOS, XXV, 178). But it is not certain that the Yezidis believe in Melek Tâ'us as an evil spirit. In the history of religion the god of one people is the devil of another. Asura is a deity in the Rig Veda and an evil spirit only in later Brahman theology. In Islam the gods of heathenism are degraded into jinns, just as the gods of North Semitic heathenism are called še îrîm (hairy demons) in Lev. 17:7; or as the gods of Greece and Rome became devils to early Christians. See W. R. Smith, Religion of the Semites, p. 120; Fihrist, pp. 322, 326. 
Professor M. Lidzbarski ( $Z D M G, \mathrm{LI}, 592)$, on the other hand, argues that Tâ'us is the god Tammuz. His contention is based on the assumption that the word Tâ'us must embody an ancient god; that in Fihrist, 322, the god Tâuz ت in Kurdish, the language of the Yezidis, $m$ is frequently changed to $w$. This theory also is untenable, for one might guess at any ancient god. The exact form of the name "Tauz" is uncertain (see Chwolsohn, Die Ssabier, II, 202); the statement that in Kurdish $m$ is frequently changed to $w$ is not true, if one would set it up as a grammatical rule to explain such phenomena; the Kurdish-speaking people never pronounce Tammuz, "Tauz;" and, finally, in the Yezidi conception of Melek Ṭ̂'us there are no traces of the notion held respecting Tammuz.

31. Such a state of affairs finds a historical parallel in other religions. Take, for example, Christianity. In it we find that the distinctive characteristics of the founder have been wrapped up in many foreign elements brought in by those who came from other religions.

30.* The whole sentence in which the phrase, جبل الاسود, occurs is not found in Chabot, Parry, the Syriac manuscript which was written by Priest Ishaka and published by Samuel Giamil (Rome, 1900), nor in the Arabic manuscript of Šamir.

The Syrian Malkites called the mountain on which the convent of Mar Elia was built 15ool |; tified by some with the Greek $\Delta o v \dot{\xi}$ (Alixis, XII, 12) and with the Arabic

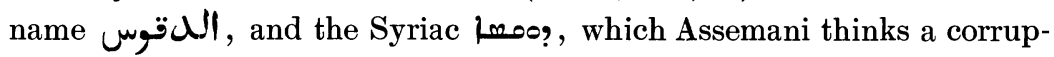
tion of the Arabic term for Jerusalem; see Journal of Theological Studies, II, $176-78 .^{1}$

31.* The Syriac text of Giamil, Monte Singar, 12, identifies Naumi with Noah. ${ }^{1}$

32. son;' ef. Giamil, loc. cit.

33. امسكوها واحرقورا. The Syriac text of Chabot (p. 103), the Arabic MS of Šamir (p. 12), and Parry's translation (p. 381), show that it was Noah who caught and burned the serpent.

34. ستبذب امغ واحلهة وراك . The Syriac text of Chabot (p. 104) reads ;

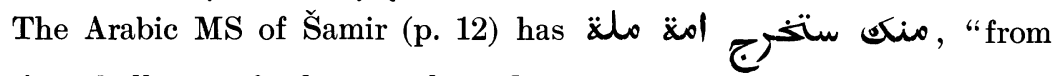
thee shall come forth a people and a nation; Parry (Six Months in a Syrian Monastery, 381) agrees with the reading of Šamir.

1 By an oversight in the numbering of the notes, 30 and 31 have been repeated; $30^{*}$ and 31* refer to the Arabic text, p. 124, 1. 1, and p. 126, last line, respectively. 
35. بلقب is a transliteration of the Syriac بحص a denominative verb from "דمصص 'to oppose, to contradict;' cf. also Giamil, p. 15; Chabot, p. 104. The MS of Šamir reads تناذى وتضم ; Parry's translation agrees with this.

36. Giamil (p. 48) has: أرب or , "Yezîd descended from King Sapor."

37. Cf. Bar Hebraeus, Chronicon Eccles., ed. Abeloos-Lamy, I, 219, where he speaks of the Borborians; see also note 29.

38. يكفظو ثلاثنة ايام. The text seems to be corrupt, so also the Syriac text of Chabot (p. 108), and cf. Parry (p. 383). Giamil (p. 33), seems to have the right reading:

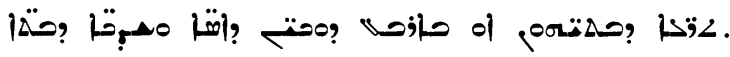

39. راس النسنة is Kurdish. It is an equivalent to the Arabic

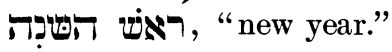

40. شשקץ is the Hebrew word "detestation, detestable thing;"

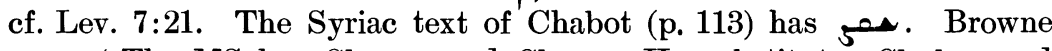
says: "The MS has Shuqus and Shaqs. He substitutes Shuhus and Shahs, "personages," or "images," Parry, op. cit., pp. 384, 385, 386. The Hebrew word is an opprobrious term for idols, and used to express the deepest abhorrence of them. See Encyclopaedia Biblica, "Idol."

41. خاسيب is an obscure term. The same reading is found in Šamir's MS; see also Chabot, p. 113. Browne regards it a corrupt form the Arabic خزيتة "treasury" (Parry, p. 385).

42. كبد كبد The Syriac text of Chabot (p. 14), and Giamil (p. 12), have كصبرمد ; كفلوش (p. 16). Browne (Parry, p. 386) reads gavdush and regards it a corruption of the Persian gavgusht.

43. هرا, is a transliteration of the Syriac lijol (⿳亠丷ápoov) "stole;" cf. Giamil, p. 77. Chabot (p. 115) has إن ; Šamir (p. 16) زنار "girdle," and so Browne (Parry, p. 386). The Syriac text of Chabot adds " which is a corruption of 12 , "a bond;" the Arabic MS of Šamir (p. 16) has قبالا (so Parry, p. 386), which is a transliteration of the Syriac مصن.

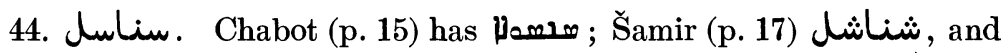
so Parry (p. 387); but he reads shamashil, and regards it "an Arabic form of plural from shemshal." I cannot conjecture the etymology of سناسل

45. It is the name of some religious practice. Cf. Giamil, p. 75 . 
47. هوطوقى is Kurdish.

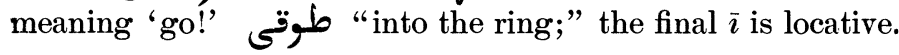

47.* ملك طاوس) لوسيفروس (Isa. 14:12). The compiler, Dâud Aṣ-Ṣâig, was a Romanized Syrian, and was probably familiar with the Latin Lucifer.

48. А. н. 295 (A. D. 807-8). This is the date of Al-Multadir's accession, who reigned till А. н. 320 (А. D. 932); cf. W. Muir, The Caliphate, p. 559.

49. The life of Manșûr-al-Ḥallâj is given in Fihrist (ed. Flügel), p. 190.

50. The life of 'Abd-al-Kâdir of Jilân is given in Jami's Nafahat (ed. Lee), p. 584.

51. The Hakkari country is a dependency of Mosul, and inhabited by Kurds and Nestorians; cf. p. 104. Ibn Hauḳal, Kîtâb al-Masâlik walMamâlik (ed. M. J. De Goeje), pp. 143 f.

52. Yaḳ̂ut, IV, 373, calls it Laileš (ليلش), and says that Šeih 'Adi lived there.

53. Presumably Yezîd bn Mu'âwiya, the second caliph in the Omayyid dynasty, who reigned, A. D. 680-83; cf. W. Muir, The Caliphate, p. 327.

54. The life of Hasan al-Bașrî is given in Ibn Hallikân. He is not to be identified with Ḥasan al-Bașri (died 110 A. н.), who, according to Mohammedan tradition, first pointed the Koran text, with the assistance of Yaḥyâ bn Yamar.

55. In Menant's Yezidis, 48, the names of these seven angels are somewhat differently given. According to Mohammedan tradition Zazil or Azazil was the original name of the devil.

56. By the "throne" (العرش) here is meant the throne of God, and by the "carpet" (الفرش) the earth; cf. Sura 60:131.

57. According to Moslem belief, wheat was the forbidden fruit; see Baiḍ̂awi on Sura, ii, 33 .

58. Kunsiniyat is an obscure term.

59. 'Ain Sifni is about five miles from Ba'adrie; cf. Layard, Nineveh, I, 272.

60. Yakût (III, 158) mentions a similar tradition.

61. These are indications of Mohammedan influence and censorship, for no Yezidi will ever write in his sacred book such words as Šeitân, Sar, etc.

62. That is, those of other religions.

63. Sanjak سi is a Turkish word, meaning a banner; it is the name by which the Yezidis generally designate the sacred image of Melek Tâ'us.

64. See notes 28 and 39.

* No. 47 is accidentally repeated. 
65. The Harranian New Year fell on the first day of April, and on the sixth day they slaughtered an ox and ate it; cf. Fihrist, 322.

66. A similar practice is found among the Parsees of India, who hang a string of leaves across the entrances to their houses at the beginning of every New Year.

67. According to Babylonian mythology, human destiny was decreed on the New Year's day and sealed on the tenth day; cf. the Hibbert Journal, V, January, 1907. And according to Talmud (Mišna, Roš hašana, $1: 2$ ), New Year's is the most important judgment day, on which all creatures pass for judgment before the Creator. On this day three books are opened, wherein the fate of the wicked, the righteous, and those of the intermediate class are recorded. Hence prayer and works of repentance are performed at the New Year from the first to the tenth days, that an unfavorable decision might be averted; cf. Jewish Encyclopedia, "Penitential Day." R. Akiba says: "On New Year day all men are judged; and the decree is sealed on the Day of Atonement;" cf. ibid., "Day of Judgment."

68. Ibrîk al-Aṣfar means 'the yellow pitcher.'

69. Baḳbûk is a pitcher with a narrow spout.

70. Mar Mattie is a Syrian monastery about seven hours' ride east of. Mosul, generally known by the name of Šeih Mattie, in accordance with the general custom of sheltering a Christian saint beneath a Moslem title. Elijah is known as Al-Huder, "the green one." Aphraates was bishop of Šeih Mattie. The church of this monastery is a large building, chiefly interesting as containing the tomb of the great Bar Hebraeus, known as Abu-l-Faraj, who was ordained at Tripolis, and became in 1264 A. D. Metropolitan of Mosul. He lies buried, with his brother Barsom, in the "Beth Kadišeh (sanctuary) of the church, and over them is placed the inscription: "This is the grave of Mar Gregorias, and of Mar Barsome his brother, the children of the Hebrew, on Mount Elpep" (the Syriac name for Jabal Maḳlûb).

71. Kani in Kurdish means a spring; zarr, yellow. In Kurdish, as in Persian, the adjective usually follows the modified noun; cf. Tartibi Jadid, Ta'alimi Faresi. The New Method for Teaching Persian (in the Turkish language, ed. Kasbar, Constantinople, А. н. 1312), p. 18.

72. Jawîs (جاويش) is a Turkish word, signifying a sergeant.

73. This ceremony, as well as the names 'Arafat, Zamzam, etc., seems to be a mere copy of the Meccah Pilgrimage. 'Arafât (عرفات) "The Mount of Recognition," is situated twelve miles from Mecca, a place where the pilgrims stay on the ninth day of the day of the pilgrimage, and recite the midday and afternoon prayer. The Mohammedan legend says, that when our first parents forfeited heaven for eating wheat, they were cast down from the Paradise, Adam fell on the Isle of Ceylon, and Eve near 


\section{The American Journal of Semitic Languages}

Jiddah (the port of Mecca) in Arabia; and that, after separation of 200 years, Adam was conducted by the Angel Gabriel to a mountain near Mecca, where he found and knew his wife, the mountain being then named 'Arafat, "Recognition."

74. The god Nisroch of Scripture, II Kings 19: 37; Isa. 37: 38.

75. See note 47.

76. A superstitious name signifying an ill omen.

77. That is, public prayers like those of the Mohammedans and of the Christians; cf. Al Mašrik, II, 313.

78. The text has lod "her hand."

79. While the Yezidis venerate 'Abd al-Ḳâdir of Jîlân, the Nuṣairis curse him; cf. JAOS, VIII, 274.

80. This belief is taken from Mohammedanism.

81. The Arabs worshiped a deity under the form of a nasr (eagle), Aš-Š̆ahrastânî, II, 434; Yaḳut, IV, 780; The Syriac Doctrine of Addai (ed. George Philips), p. 24.

82. Cf. Gen. 1:2, and the Babylonian Creation Epic.

83. That is the spring of Šeih 'Adî.

84. The reference is to Jabal Makluab, which, according to the Yezidi belief, moved from its place near Lališ to enable every Yezidi, wherever he may be, to direct his morning prayers toward the tomb of 'Adî.

85. The Moslem begins his prayer by cursing the devil.

86. That is a person of the same faith, a Yezidi.

87. A Nusairi, on the contrary, may become a Mohammedan with a Mohammedan, a Christian with a Christian, and a Jew with a Jew; cf. JAOS, VIII, 298.

88. The Șabians did not eat purslane, garlic, beans, cauliflower, cabbage, and lentils; cf. Bar Hebraeus, At-Târîb, ed. A. Șalḥani, Beirut, $1890,266$. 